\title{
The Effect of Stress Control and Expectation on Satisfaction with Teacher Colleagues in MTsN (Islamic Junior High School) Stabat, Langkat Regency, Indonesia
}

\author{
Nurmaisari Nasution ${ }^{1}$, Tien Rafida ${ }^{2}$ \\ ${ }^{I}$ Teacher in MIN 15 Langkat, Indonesia \\ ${ }_{2}^{2}$ Postgraduate Program in Islamic Education, Tarbiyah and Teacher Training Faculty, UIN Sumatera Utara, \\ Indonesia \\ titinrafida@gmail.com
}

\begin{abstract}
This paper deals with The Effect of Stress Control and Expectation on Satisfaction with Teacher Colleagues in MTsN (Islamic Junior High School) Stabat, Langkat Regency, Indonesia. The conditions that are not conducive where among the teachers there are still those who do not agree to carry out work on the decisions that have been determined are always pros and cons. This research is quantitative research, a type of correlation research using descriptive and inferential approaches and by classifying independent variables and dependent variables. The result shows that there is a moderate tendency in stress control variables, expectation variables and satisfaction variables with teacher colleagues tend to be less. In other words, stress control and expectation together can increase satisfaction with teacher colleagues.
\end{abstract}

Keywords : Stress Control, expectation, satisfaction, Teacher Colleagues

\section{Introduction}

Satisfaction with teaching colleagues in a job is an important problem because it relates to the effectiveness of the teacher who definitely influences student achievement. As Robbins (2008: 113) suggests that when overall productivity and satisfaction data is collected for organizations, we find that organizations that have more satisfied employees tend to be more effective than organizations that have employees who are less satisfied. On the one hand it is said that satisfaction with colleagues causes an increase in performance so that satisfied workers will be more productive. On the other hand workers who are satisfied with their colleagues will be more active in carrying out their duties and carrying out their duties responsibly, teachers who feel dissatisfied with some aspects of their work will tend to leave their profession as teachers.

But based on the results of a preliminary study conducted through observations and interviews, it was revealed that there were several important problems related to satisfaction with teacher colleagues, namely: There was still a lack of organizational attention to achieving teacher expectations, where the madrasa was still less concerned about complaints teachers with school management are less in line with expectations, more teachers are less concerned as a result of lack of cooperation with colleagues. There is still a lack of motivation for teachers from the madrasa principals to develop teachers 'professional abilities through training and study education to a higher level, the quality of teachers is still low both in terms of ability and motivation to work optimally, lack of parental concern for the development of students' progress, there are still teachers who are late for school and do not immediately enter the class to teach even though the entrance bell has sounded. Less creative teachers create an interesting and comfortable learning atmosphere.

In addition, conditions that are not conducive where there are still fellow teachers who do not agree to carry out work on the decisions that have been determined, there are always 
pros and cons. Teachers only do teaching assignments and care less to provide solutions to teachers who have difficulty in handling problematic students. On the other hand the closeness to leaders is still the principal priority of school principals in the appointment of additional positions to teachers not based on ability. Another fact was found, not fulfilling expectations to improve the quality of education from the side of the head of the madrasa; appointment of madrasa principals without going through the selection process and training of madrasa head candidates, mastery of the madrasa principals to the duties and responsibilities is still very low this causes not the maximum performance of the principals, weak empowerment of teachers and education staff, development support for professional teacher improvement is still low, implementation madrasah head supervision is unclear, and teacher performance assessment is unclear.

\section{Review of Literatures}

\subsection{Job Satisfaction}

Rivai and Mulyadi (2003: 246) say job satisfaction is an assessment of workers about how far their overall work satisfies needs. Job satisfaction is also a general attitude which is the result of several special attitudes towards work factors, adjustment and individual social relationships outside of work. Mathis and Jackson in Sopiah (2008: 170) that job satisfaction is a positive emotional statement that is the result of evaluation of work experience.

Riggio in Hadjam and Nasiruddin (2003: 34), job satisfaction is largely defined as the feelings and behavior of individuals regarding their work. All aspects of good and bad work, positive and negative will play a role in creating this feeling of satisfaction. Davis and Newstroom (2002: 234) state that job satisfaction is a set of employee feelings about whether or not their work is pleasant.

Hasibuan (2001: 54) defines job satisfaction as an emotional attitude that is pleasant and loves his job. This attitude is reflected by work morale, discipline, and work performance. There is an important difference between these feelings and other elements of employee attitudes. Job satisfaction is a relative feeling of pleasure or displeasure that is different from objective thinking and behavioral desires.

Sutrisno (2010: 319) argues that job satisfaction is: (a) an attitude and emotional reaction of a person towards work. This form of reaction can be satisfied or dissatisfied with the job, (b) one's job satisfaction depends on its perception of the magnitude of the difference between what which is the expectations and needs of employees for work with the perceived reality, and (c) the level of employee satisfaction is a combination and assessment of employees of various occupational factors that are highly dependent on work factors and individual employee factors. Teachers who feel satisfied with their jobs will have a positive attitude to work so that they will encourage them to do their best work, on the contrary there is absenteeism, poor work, teaching lack of passion, theft, low achievement, teacher displacement / change as a result of teacher's dissatisfaction with the organization's treatment of him.

\subsection{Understanding Stress}

Stress is an adaptive response, through individual characteristics and / or psychological processes directly to actions, situations and external events that give rise to specific demands both physically and psychologically on the individual concerned. 
Stress terminology was first put forward by Walter Cannon in 1932, a physiologist from Harvard University who said "stressed his observation that organisms tend to" bounce back "or" resist "deforming influence from external forces". (Rice, 1999: 7). Cannon argues that when an organism perceives a threat originating outside itself, the organism tends to attack the threat or survive.

Hans Selye, often referred to as the Father of Modern Stress, or referred to as the grand master of stress research, made a very significant contribution in the field of stress, when in 1936 he stated what was called "General Adaptation Syndrome (GAS)". Selye provides a definition that "stress is non-specific response to body disturbs to body equilibrium". That is to say stress is a non-specific response that causes bodily balance disorders. According to him when the organism is faced with a stressor, he will encourage himself to take action. The business is regulated by the adrenal gland which increases the activity of the sympathetic nervous system. Individuals will respond with the same physiological reaction pattern (nonspecific response) to the disturbed body until the body becomes balanced again. According to Selye, a response to stress can produce a positive outcome called "eustress", or produce a negative outcome called "distress", therefore stress is not solely about tension, stress also causes positive consequences, so stress does not need to be avoided. (Kreitner \& Angelo Kinicki, 2007: 599).

Robbins (2007: 793) defines stress as a dynamic condition in which individuals face opportunities, constraints, or demands related to what they really want and whose results are perceived as uncertain but important. According to Charles D. Spielberger in Rivai and Mulyadi, (2011: 307) states that stress is external demands regarding a person, such as objects in the environment or a stimulus that is objectively dangerous. Stress is also usually interpreted as pressure, tension or unpleasant disturbances that come from outside a person. In line with that, Colquitt (2009: 142) defines stress as a psychological response to demands in which something is at stake and faces the demands of a burden that exceeds one's capacity or resources.

\subsection{Motivation}

Motivation is a key determinant in improving employee performance. Wexley \& Yukl in As'ad (2003: 45) suggest that the notion of motivation is giving or generating motives. Can also be interpreted things or circumstances into motives, so, work motivation is something that gives rise to enthusiasm or work motivation. Robbins-judge (2008: 222) defines motivation as a process that explains the intensity, direction, and perseverance of an individual to achieve his goals. According to Hasibuan (2008: 141) Motivation comes from the Latin word movere which means encouragement or movement. So, motivation is the thing that causes, channel, and supports human behavior, so that they want to work hard and enthusiastically achieve optimal results. While Sopiah (2008: 170) defines motivation as a condition in which a person's effort and will is directed towards achieving certain results or goals.

Chung \& Megginson in Gomes (2003: 177) asserts that "motivation is defined as goaldirected behavior. It concerns the level of effort in pursuing a goal ... it is related to employee satisfaction and job performance (motivation is defined as behavior aimed at the target. Motivation is related to the level of effort carried out by someone in pursuit of a goal ... motivation is closely related to employee satisfaction and job performance). 


\section{Research Methods}

This research was carried out at MTsN (Islamic Junior High School) Stabat, Langkat Regency and Research from July to September 2018. The population is a generalization region consisting of subjects that have certain qualities and characteristics set to be studied and then drawn conclusions (Sugiyono, 2009: 117). The target population in this study were teachers of MTsN (Islamic Junior High School) Stabat, Langkat Regency, which numbered 54 people. Noting the size of the population of 54 people, the sample of this study is all members of the population or total sampling. So the sample of this study was 54 people. This research is quantitative research, a type of correlational research using descriptive and inferential approaches and by classifying independent variables and dependent variables. The nature of descriptive research describes the facts as they are. These facts are reviewed to see the contribution of independent variables to the dependent variable. This research is also inferential which is not just analyzing and deducing data, but can predict trends that will occur in the population.

\section{Discussion}

Data from the research results presented in this study are questionnaire scores given to respondents. The description of the data presented informs the mean, mode, median, variance, standard deviation, maximum score and minimum score. Data description is also equipped with frequency distribution and histogram graph of each variable.

The results of processing data show that stress control variables have an average value or mean $=117.66 ;$ mode $=118.6 ;$ median $=118.2$; variance $=123.70 ;$ standard deviation $=$ 11.12; maximum score $=148$; and minimum score $=83$. An overview of the Data Frequency Distribution of Stress Control Variables is presented in Table 1.

Table. 1 Data Frequency Distribution of Stress Control Variables

\begin{tabular}{|l|l|l|}
\hline Interval Class & $\mathrm{f}_{\text {absolute }}$ & $\mathrm{f}_{\text {relative }}(\%)$ \\
\hline $83-92$ & 2 & 3,33 \\
\hline $93-102$ & 3 & 5,00 \\
\hline $103-112$ & 10 & 16,67 \\
\hline $113-122$ & 26 & 43,33 \\
\hline $123-132$ & 16 & 26,67 \\
\hline $133-142$ & 2 & 3,33 \\
\hline $143-152$ & 1 & 1,67 \\
\hline Total & 60 & 100 \\
\hline
\end{tabular}

The histogram graph of the attitude variables towards the cadre model is presented below: 


\section{Frequency}

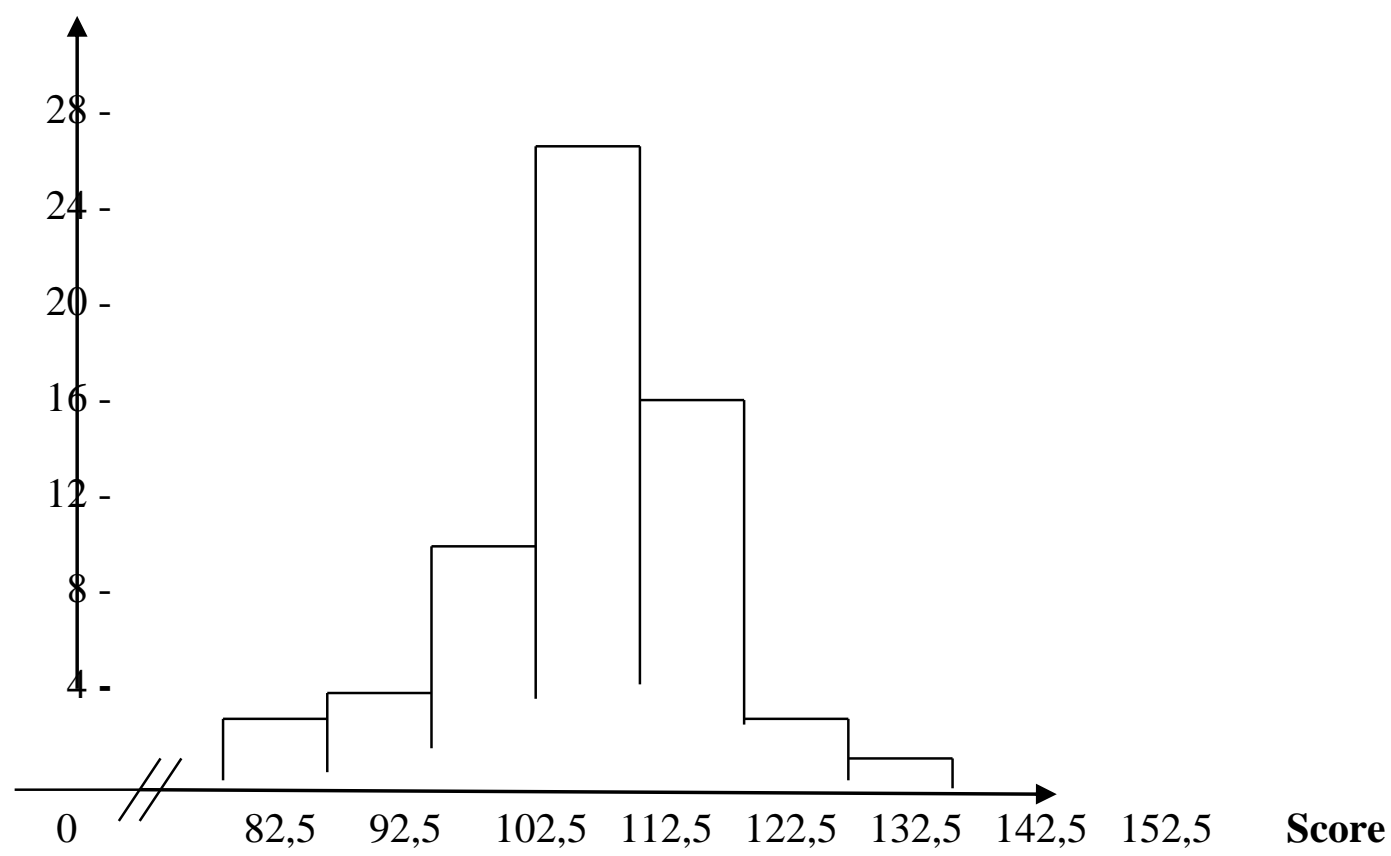

Figure. 1 Histogram Scores of Stress Control Variables

The results of data processing show that the expectation variable has an average value or mean $=114.96 ;$ mode $=114.38 ;$ median $=115.1 ;$ variance $=159.43 ;$ standard deviation $=12.62$; maximum score $=138$; and minimum score $=86$. An overview of the Variable Expectation Data Distribution is presented in Table 2.

Table. 2 Variable Expectation Data Distribution

\begin{tabular}{|l|l|l|}
\hline Interval Class & $\mathrm{f}_{\text {absolute }}$ & $\mathrm{f}_{\text {relative }}(\%)$ \\
\hline $86-93$ & 4 & 6,67 \\
\hline $94-101$ & 5 & 8,33 \\
\hline $102-109$ & 9 & 15,00 \\
\hline $110-117$ & 17 & 28,33 \\
\hline $118-125$ & 12 & 20,00 \\
\hline $126-133$ & 9 & 15,00 \\
\hline $134-141$ & 4 & 6,67 \\
\hline Total & 60 & 100 \\
\hline
\end{tabular}

Then the expectation graph histogram is presented as follows: 


\section{Frequency}

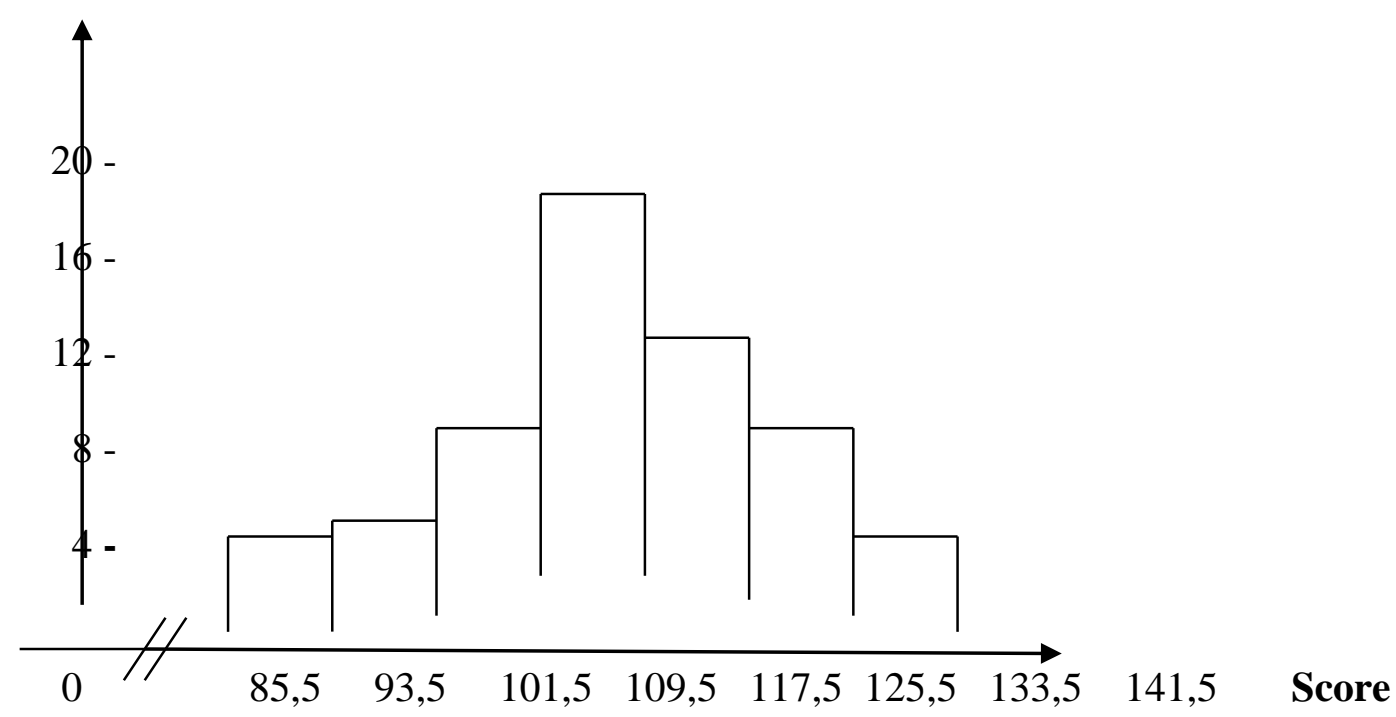

Figure. 2 Histogram of Variable Expectation Score

The results of data processing variable satisfaction with colleagues show an average value or mean $=106.88 ;$ mode $=105.81 ;$ median $=108.4 ;$ variance $=118.74 ;$ standard deviation $=10.89$; maximum score $=127$; and minimum score $=83$. An overview of the Variable Data Distribution Satisfaction with colleagues is presented in Table 3.

Table. 3 Variable Data Distribution Satisfaction with colleagues

\begin{tabular}{|l|l|l|}
\hline Interval Class & $\mathrm{f}_{\text {absolute }}$ & $\mathrm{f}_{\text {relative }}(\%)$ \\
\hline $83-89$ & 4 & 6,67 \\
\hline $90-96$ & 6 & 10,00 \\
\hline $97-103$ & 13 & 21,67 \\
\hline $104-110$ & 15 & 25,00 \\
\hline $111-117$ & 11 & 18,33 \\
\hline $118-124$ & 8 & 13,33 \\
\hline $125-131$ & 3 & 5,00 \\
\hline Total & 60 & 100 \\
\hline
\end{tabular}

Furthermore, the histogram graph of variable satisfaction with colleagues is presented as follows: 


\section{Frequency}

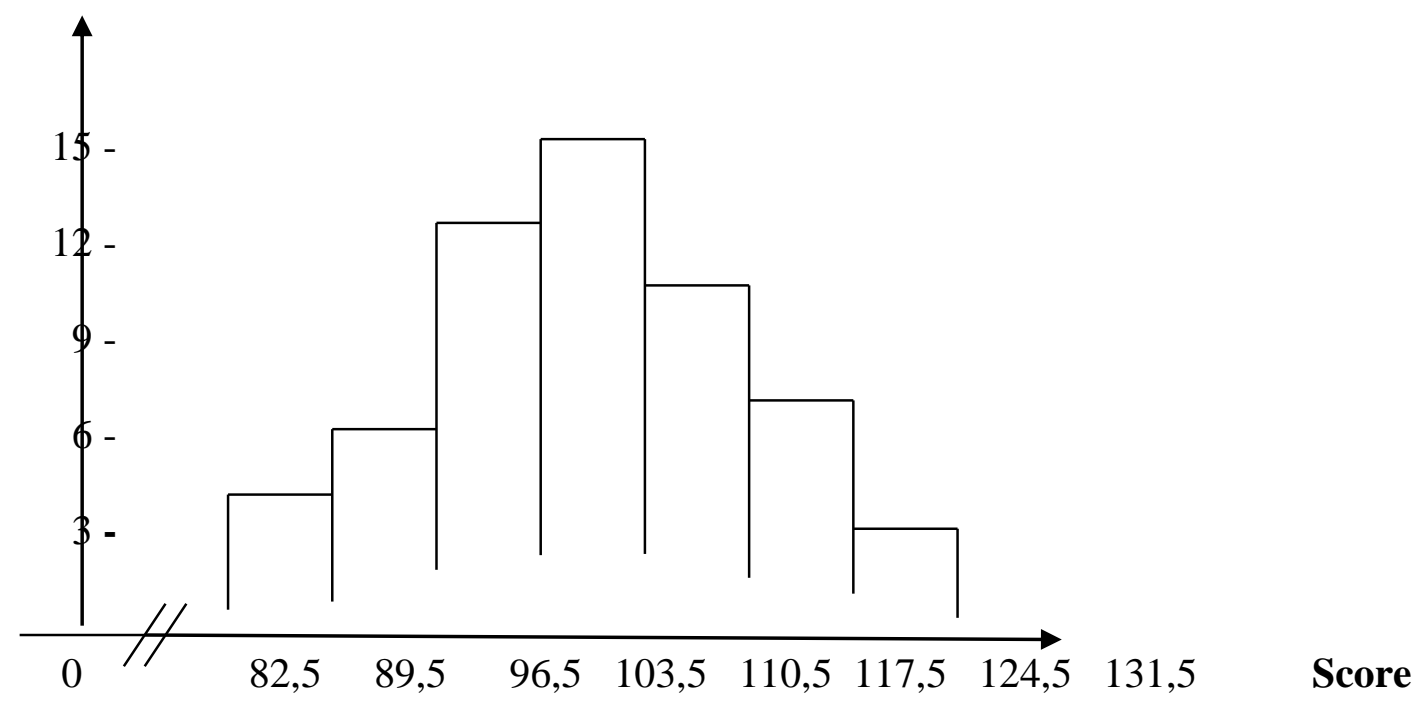

Figure. 3 Variable Histogram Score Satisfaction with colleagues

Testing the tendency of data for each study variable used the average ideal score and ideal standard deviation of each variable which was then categorized into 4 (four) categories, namely high, medium, low and low.

1. Test the tendency of stress control variables

The test results of the tendency of stress control variables $\left(\mathrm{X}_{1}\right)$ are illustrated in Table 4 below:

Table. 4 Tendency Level of Stress Control Variables $\left(\mathrm{X}_{1}\right)$

\begin{tabular}{|l|l|l|l|}
\hline Interval Score & Frequency & $\mathrm{f}_{\text {relative }}(\%)$ & Category \\
\hline$\geq 127$ & 13 & 21,67 & High \\
\hline $98-126$ & 45 & 75,00 & Medium \\
\hline $68-97$ & 2 & 3,33 & Less \\
\hline$\leq 67$ & - & - & Low \\
\hline Total & 60 & 100 & \\
\hline
\end{tabular}

Based on the data in Table 4, it can be explained that the stress control variable in the high category is $21.67 \%$, the medium category is $75 \%$, the category is less than $3.33 \%$ and the low category is $0 \%$. Thus it can be concluded that stress control in this study tends to be moderate as evidenced by $75 \%$ of respondents in the medium category.

2. Test the trends of the Expectation variable

The results of testing the trend of expectation variables $\left(\mathrm{X}_{2}\right)$ are illustrated in Table 5 below:

Table. 5 Expectation Level of Variable Expectations $\left(\mathrm{X}_{2}\right)$

\begin{tabular}{|l|l|l|l|}
\hline Interval Score & Frequency & $\mathrm{f}_{\text {relative }}(\%)$ & Category \\
\hline$\geq 156$ & - & - & High \\
\hline $117-155$ & 28 & 46,67 & Medium \\
\hline $78-116$ & 32 & 53,33 & Less \\
\hline$\leq 77$ & - & & Low \\
\hline Total & 60 & 100 & \\
\hline
\end{tabular}


Based on the data in Table 5, it can be described for the expectation variable in the high category $0 \%$, the medium category at $46.67 \%$, the less category at $53.33 \%$ and the low category at $0 \%$. Thus it can be concluded that the expectations in this study tend to be less as evidenced by $53.33 \%$ of the respondents in the less category.

3. Test variable trends Satisfaction with colleagues (Y)

Table. 6 Tendency of Variables Satisfaction with colleagues (Y)

\begin{tabular}{|l|l|l|l|}
\hline Interval Score & Frequency & $\mathrm{f}_{\text {relative }}(\%)$ & Category \\
\hline$\geq 148$ & - & - & High \\
\hline $111-147$ & 22 & 36,67 & Medium \\
\hline $74-110$ & 38 & 63,33 & Less \\
\hline$\leq 73$ & - & - & Low \\
\hline Total & 60 & 100 & \\
\hline
\end{tabular}

Based on the data in Table 6 can be described for the variable satisfaction with colleagues in the high category $0 \%$, the medium category is $36.67 \%$, the category is less by $63.33 \%$ and while the low category is $0 \%$. Thus it can be concluded that satisfaction with colleagues in this study tends to be less as evidenced by $63.33 \%$ of respondents in the less category.

Testing requirements analysis is intended as a requirement test to use multiple regression analysis techniques before the data is analyzed. Requirements testing carried out is normality test, linearity test and independence test between independent variables.

The results of testing the normality of the variables of this study are stress control variables, expectation variables and satisfaction variables with colleagues are likely to be normally distributed. This can be seen from the price of Liliefors observation $\left(\mathrm{L}_{\mathrm{o}}\right)$, the calculation results of each variable indicate a value that is smaller than the value of the Liliefors table $\left(\mathrm{L}_{t}\right)$. Thus the data from the three research variables came from populations that were normally distributed, so that they met the requirements to be analyzed by correlation and regression. The complete calculation can be seen in the summary of the results of the normality test in Table 7.

Table. 7 Summary of Analysis of Normality Tests

\begin{tabular}{|l|l|l|l|l|}
\hline No & Estimated Error & $\mathrm{L}_{\text {observation }}$ & $\mathrm{L}_{\text {table }}(\alpha=0,05)$ & Information \\
\hline 1 & $\mathrm{Y}$ atas $\mathrm{X}_{1}$ & 0,0760 & 0,1144 & Normal \\
\hline 2 & $\mathrm{Y}$ atas $\mathrm{X}_{2}$ & 0,1074 & 0,1144 & Normal \\
\hline
\end{tabular}

From table 7 above, it can be seen that the Liliefors observation value is smaller than the Liliefors table value, this shows the overall score of the research variable is normally distributed. For price stress control variables $\mathrm{L}_{\text {observation }}(0.0760)<\mathrm{L}_{\text {table }}(0.1144)$ thus the stress control variable thus the expectation variable on satisfaction with work is normally distributed. For expectation variables $\mathrm{L}_{\text {observation }}(0.1074)<\mathrm{L}_{\text {table }}(1.1144)$ thus the expectation variable on satisfaction with work is normally distributed.

The simple regression equation sought is a simple regression equation $\mathrm{Y}$ over $\mathrm{X}_{1}$ and $\mathrm{Y}$ over $\mathrm{X}_{2}$ with the equation model is: $=\mathrm{a}+\mathrm{bX} 1$ and $\hat{\mathrm{Y}}=\mathrm{a}+\mathrm{bX}$.

a. Test the linearity and significance of the regression variable $\mathrm{X}_{1}$ with $\mathrm{Y}$ 
The calculation results obtained by a simple regression equation $\hat{Y}=42.71+0.54 \mathrm{X}_{1}$. The complete calculation can be seen in the summary of the calculation results in Table 8 below:

Table. 8 Anava Summary Linearity Test Between $X_{1}$ and $Y$

\begin{tabular}{|l|l|l|l|l|l|}
\hline Variation Source & JK & DK & RJK & $F_{\text {count }}$ & $\mathrm{F}_{\text {table }} \alpha=0,05$ \\
\hline Total & 694671 & 60 & - & - & - \\
\hline Regresi (a) & 687154,01 & 1 & 687154,01 & & \\
Regresi (b/a) & 2164,57 & 1 & 2164,57 & 23,45 & 4,008 \\
Residue & 5352,42 & 58 & 92,28 & & \\
\hline Tuna Cocok & 3334,07 & 31 & 107,55 & 1,43 & 1,876 \\
Galat & 2018,35 & 27 & 74,75 & & \\
\hline
\end{tabular}

Information:

$\mathrm{JK}=$ sum of squares

$\mathrm{DK}=$ degree of freedom

RJK = average number of squares

From the table above, it can be seen that $\mathrm{F}$ count regression is obtained 23.45 while the price of $\mathrm{F}$ table with $\mathrm{dk}$ numerator 1 and the denominator 58 at the significance level $\alpha=0.05$ is 4.008. It turns out that the price of $F$ regression (23.45) is greater than the price of $F$ table (4.008), it can be concluded that the regression direction coefficient $\mathrm{Y}$ on $\mathrm{X}_{1}$ means at the significance level $\alpha=0.05$.

Furthermore, it is known that the price of $\mathrm{F}$ tuna matched the calculation results obtained at 1.43 while the price of $\mathrm{F}$ table with 31 numerator $\mathrm{dk}$ and 27 denominator at the significance level $\alpha=0.05$ is 1.876 . Because the price of $F$ tuna matches count 1.43 smaller than the value of $\mathrm{F}$ table 1.876. This shows the stress control variable $(\mathrm{X} 1)$ on the satisfaction variable with colleagues $(\mathrm{Y})$ with the regression line equation $\hat{\mathrm{Y}}=42.71+0.54 \mathrm{X}_{1}$ is linear.

The calculation of regression meanings $\mathrm{Y}$ on $\mathrm{X}_{1}$ shows the price of $\mathrm{Fh}>\mathrm{Ft}$. This means that the regression direction coefficient $Y$ for $X_{1}$ is significant at the level of $\alpha=0.05$. Thus the regression equation $\hat{Y}=42.71+0.54 \mathrm{X}_{1}$ can be accounted for to draw conclusions about the effect of stress control on satisfaction with colleagues. In other words an increase in one stress control score will increase by 0.54 scores on satisfaction with colleagues.

b. Test the linearity and regression significance of $\mathrm{X}_{2}$ variables with $\mathrm{Y}$

The results of linearity calculations obtained a simple regression equation $\hat{Y}=25.79+$ $0.51 X_{2}$. The summary of the calculation results can be seen in Table 9.

Table. 9 Anava summary Linearity Test between $\mathrm{X}_{2}$ and $\mathrm{Y}$

\begin{tabular}{|l|l|l|l|l|l|}
\hline Variation Source & JK & DK & RJK & $\mathrm{F}_{\text {count }}$ & $\mathrm{F}_{\text {table }} \alpha=0,05$ \\
\hline Total & 694671 & 60 & - & - & - \\
\hline Regresi (a) & 687154,01 & 1 & 687154,01 & & \\
Regresi (b/a) & 2407,12 & 1 & 2407,12 & 27,32 & 4,008 \\
Residue & 5109,87 & 58 & 88,10 & & \\
\hline Tuna Cocok & 2925,23 & 33 & 88,64 & \multirow{2}{*}{1,014} & \multirow{2}{*}{1,905} \\
Galat & 2184,64 & 24 & 87,38 & & \\
\hline
\end{tabular}

Before conducting correlation and regression analysis, it is necessary to know the relationship between stress control free variables $\left(\mathrm{X}_{1}\right)$ and expectations $\left(\mathrm{X}_{2}\right)$ are truly independent or do not have a correlation with each other, it is necessary to test independence 
between independent variables. The results of testing analysis between stress control variables $\left(\mathrm{X}_{1}\right)$ and expectations $\left(\mathrm{X}_{2}\right)$ have a correlation of 0.166.

Table. 9 Summary of the Independence Test between Variables $X_{1}$ With $X_{2}$

\begin{tabular}{|l|l|l|l|l|}
\hline Correlation & $\begin{array}{l}\text { Correlation coefficient } \\
(\mathrm{r})\end{array}$ & $\begin{array}{l}\text { Determinant coefficient } \\
\left(\mathrm{r}^{2}\right)\end{array}$ & $\mathrm{t}$ count & $\begin{array}{l}\mathrm{t} \text { table } \\
(\alpha=0,05)\end{array}$ \\
\hline $\mathrm{rX}_{1} \mathrm{X}_{2}$ & 0,075 & 0,005 & 0,57 & 1,671 \\
\hline
\end{tabular}

From table 9 above shows that the correlation coefficient between stress control variables $\left(\mathrm{X}_{1}\right)$ and expectations $\left(\mathrm{X}_{2}\right)$ is 0.075 with a coefficient of determination $\left(\mathrm{r}^{2}\right)$ of 0.005 . Through the $\mathrm{t}$ test that has been done it turns out that $\mathrm{t}$ count $=0.57$ while the value of $\mathrm{t}$ table $=1.671$. Because $t_{\text {count }}(0.57)<t_{\text {table }}(1.671)$, this shows that the two independent variables do not have a meaningful relationship so the two independent variables are independent variables.

\section{Hypothesis testing}

\section{First hypothesis}

The statistical hypotheses tested are:

$\mathrm{H}_{\mathrm{o}}: \rho \mathrm{y}_{1} \leq 0$

$\mathrm{H}_{1}: \rho \mathrm{y}_{1}>0$

Testing to determine the effect of stress control variables $\left(\mathrm{X}_{1}\right)$ with satisfaction with colleagues $(\mathrm{Y})$ used a simple regression analysis, while $\mathrm{t}$ test was used to test its significance. Simple regression between stress control variables $\left(\mathrm{X}_{1}\right)$ on satisfaction with colleagues $(\mathrm{Y})$ is presented in summary in Table 10.

Table. 10 Summary of $X_{1}$ Analysis Results against $Y$ and the Test of Meaning

\begin{tabular}{|l|l|l|l|l|l|}
\hline Correlation & $\begin{array}{l}\text { Correlation coefficient } \\
(\mathrm{r})\end{array}$ & $\begin{array}{l}\text { Determinant coefficient } \\
\left(\mathrm{r}^{2}\right)\end{array}$ & $\mathrm{t}$ count & $\begin{array}{l}\mathrm{t} \text { table } \\
(\alpha=0,05)\end{array}$ \\
\hline $\mathrm{rX}_{1} \mathrm{Y}$ & 0,540 & 0,291 & 4,88 & 1,671 \\
\hline
\end{tabular}

From table 10 above shows that the coefficient between stress control variables $\left(\mathrm{X}_{1}\right)$ with satisfaction with colleagues $(\mathrm{Y})$ is 0.540 with a coefficient of determination $\left(\mathrm{r}^{2}\right)$ of 0.291 . Through the $\mathrm{t}$ test that has been done it turns out that $\mathrm{t}$ count $=4.88$ while the value of $\mathrm{t}$ table $=$ 1.671. Because $t$ count (4.88)> $t$ table (1.671), this indicates that there is a positive and significant effect of stress control variables on satisfaction with colleagues with the form of predictive equations through regression lines $\hat{Y}=42.71+0.54 \mathrm{X}_{1}$.

Based on the above analysis it can be concluded that stress control has a positive and significant influence with satisfaction with colleagues. This shows that the first hypothesis of this study has been empirically tested.

\section{Second Hypothesis}

The hypothesis statistics tested are:

$\mathrm{H}_{\mathrm{o}}: \rho \mathrm{y}_{2} \leq 0$

$\mathrm{H}_{1}: \rho \mathrm{y}_{2}>0$

Tests to determine the effect of expectation variables $\left(\mathrm{X}_{2}\right)$ on satisfaction with colleagues (Y) used simple regression analysis, while t test was used to test its significance. The results of 
a simple regression analysis between expectation variables $\left(\mathrm{X}_{2}\right)$ and satisfaction with colleagues (Y) are presented in summary in Table 11.

Table. 11 Summary of $X_{2}$ Analysis Results against $Y$ and the Test of Meaning

\begin{tabular}{|l|l|l|l|l|}
\hline Correlation & $\begin{array}{l}\text { Correlation coefficient } \\
(\mathrm{r})\end{array}$ & $\begin{array}{l}\text { Determinant coefficient } \\
\left(\mathrm{r}^{2}\right)\end{array}$ & $\mathrm{t}$ count & $\begin{array}{l}\mathrm{t} \text { table } \\
(\alpha=0,05)\end{array}$ \\
\hline $\mathrm{rX}_{2} \mathrm{Y}$ & 0,570 & 0,324 & 5,27 & 1,671 \\
\hline
\end{tabular}

\section{Third Hypothesis}

The hiptesis statistics tested are:

$\mathrm{H}_{\mathrm{o}}: \rho \mathrm{y}_{12} \leq 0$

$\mathrm{H}_{1}: \rho \mathrm{y}_{12}>0$

Tests to determine the effect of stress control variables $\left(\mathrm{X}_{1}, 1\right)$ and expectations $\left(\mathrm{X}_{2}\right)$ together with satisfaction with colleagues $(\mathrm{Y})$ used multiple regression analysis, while to test their significance used $\mathrm{F}$ test. The results of multiple regression analysis and coefficient significance test the correlation can be seen in the summary of the calculation results in Table 12.

Table. 12 Summary of Results of Multiple Regression Analysis and Meaningful Tests $X_{1}$ and $\mathrm{X}_{2}$ variables with $\mathrm{Y}$

\begin{tabular}{|l|l|l|l|l|}
\hline Correlation & $\begin{array}{l}\text { Correlation coefficient } \\
(\mathrm{r})\end{array}$ & $\begin{array}{l}\text { Determinant coefficient } \\
\left(\mathrm{r}^{2}\right)\end{array}$ & $\mathrm{F}_{\text {count }}$ & $\begin{array}{l}\mathrm{F}_{\text {table }} \\
(\alpha=0,05)\end{array}$ \\
\hline $\mathrm{Ry}_{1.2}$ & 0,755 & 0,570 & 67,85 & 3,162 \\
\hline
\end{tabular}

The results of the analysis in table 12 above show that the multiple regression coefficient between stress control variables $\left(\mathrm{X}_{1}\right)$ and expectations $\left(\mathrm{X}_{2}\right)$ of satisfaction with colleagues $\left(\mathrm{Ry}_{1.2}\right)$ is 0.755 . After the $\mathrm{F}$ test, it turns out $\mathrm{F}$ count $(67.85)>\mathrm{F}$ table (3.162) at $\alpha=0.05$, so the multiple regression coefficient is significant and positive.

The coefficient of determination shows the contribution of stress control and expectations of satisfaction with colleagues by $57 \%$ and the remaining $43 \%$ is estimated to come from other variables not included in this study. Furthermore, it can be stated that the double relationship of the independent variable to the dependent variable takes the form of a predictive relationship with its regression equation $\hat{Y}=3.37+0,506 \mathrm{X}_{1}+0.484 \mathrm{X}_{2}$.

Table. 13 Summary of Multiple Regression Analysis

\begin{tabular}{|l|l|l|l|l|l|}
\hline Variation Source & JK & DK & RJK & F count & $\begin{array}{l}\text { F table } \\
(\alpha=0,05)\end{array}$ \\
\hline $\begin{array}{l}\text { Regresi } \\
\text { Residue }\end{array}$ & 4312,68 & 2 & $\begin{array}{l}2156,34 \\
56,21\end{array}$ & 38,36 & 3,162 \\
\hline Total & 7516,99 & 59 & & & \\
\hline
\end{tabular}


Table. 14 Summary of Relative Contributions and Effective Donations Each Predictor Variable

\begin{tabular}{|l|l|l|}
\hline Variable & Relative Donation (\%) & Effective Donations (\%) \\
\hline Stress Control $\left(\mathrm{X}_{1}\right)$ & 47,3 & 28,7 \\
\hline Expectation $\left(\mathrm{X}_{2}\right)$ & 52,7 & 32 \\
\hline
\end{tabular}

From table 14 above, it can be understood that stress control variables can predict satisfaction with colleagues by $28.7 \%$ while expectations can predict satisfaction with colleagues by $32 \%$.

Effective contributions from each independent variable need to be controlled or controlled on one of the independent variables. In this case the analysis technique used is a partial correlation analysis technique. The full calculation can be seen in the summary in Table 20 .

Table. 15 Summary of Partial Correlation Analysis

\begin{tabular}{|l|l|l|}
\hline Free variable & Correlation with $\mathrm{Y}$ & Determinant coefficient \\
\hline $\mathrm{R}_{\mathrm{y} 1.2}$ & 0,369 & 0,136 \\
$\mathrm{R}_{\mathrm{y} 2.1}$ & 0,397 & 0,157 \\
\hline
\end{tabular}

Partial correlation between $\mathrm{X}_{1}$ and $\mathrm{Y}$ if the variable $\mathrm{X}_{2}$ is constant is $\mathrm{R} \mathrm{y}_{1.2}=0.369$ while the determination coefficient is 0.136 . This means that stress control contributes to satisfaction with colleagues by $0.136 \times 100 \%=13 \%$, while the partial correlation between $\mathrm{X}_{2}$ and $\mathrm{Y}$ if the variable $\mathrm{X}_{1}$ is constant is $\mathrm{Ry}_{2.1}=0.397$ while the determination coefficient is 0.157 . This means that expectations of contributing to satisfaction with colleagues are $0.157 \times 100 \%=15.7 \%$.

Based on the propensity test the stress control variable data showed a high score range of $\geq 127$ of $21.67 \%$, the medium category with a score range of 98 to 126 by $75 \%$, the lack of a category with a score of 68 to 97 at $3.33 \%$ and the category low with a range of scores $\leq$ is $0 \%$. Thus, overall the respondents in this study had a tendency in moderate stress control.

The trend test of the expectation variable data shows the following categories: high, medium, less and low: high category with a score range $\geq 156$ is $0 \%$, medium category with a score range of 117 to 155 is $46.67 \%$, less category with a score of 78 to with 116 of $53.33 \%$ and while the low category with a score range of $\leq 77$ is $0 \%$. Based on the tendency of the data indicates that overall the majority of study respondents have a tendency in the expectation of the less category.

While the trend test for variable data satisfaction with colleagues shows the following categories: high, medium, less and low: high category with a score range $\geq 148$ is $0 \%$, medium category with a score of 111 to 147 is $36.67 \%$, category is less with the score ranges from 74 to 110 by $63.33 \%$ and while the low category with a score range of 73 is $0 \%$. Based on the tendency of the data indicates that overall the respondents of the study had the majority of satisfaction with colleagues in the less category.

From the results of the study, it was found that there was an effect of stress control on satisfaction with teacher colleagues of Stabat MTsN Stabat, Langkat Regency at 29.7\%, in line with these findings Steer and Porter (1983: 186) emphasized that factors that influence organizational satisfaction are work characteristics in it there are work challenges, feedback, work stress, task identification, role clarity, self-development, career, and responsibility. As is known that stress according to Robbins and Timothy (2008: 793) is an adaptive response, through individual characteristics and / or psychological processes directly to actions, situations and external events that give rise to specific demands both physically and psychologically the individual concerned. Robbins defines stress as a dynamic condition in 
which individuals face opportunities, constraints, or demands related to what they really want and whose results are perceived as uncertain but important.

\section{Conclusions}

There is a moderate tendency in stress control variables, expectation variables and satisfaction variables with teacher colleagues tend to be less. There is linearity and regression significance of stress control variables on the satisfaction variable with teacher colleagues as evidenced by the regression line equation $\hat{Y}=42.71+0,54 X_{1}$ which means that an increase in one stress control score will increase every 0.54 score on satisfaction with teacher colleagues so that results can be accounted for. Likewise there is a linearity and regression significance of the expectation variable towards the satisfaction variable with teacher colleagues as evidenced by the regression line equation $\hat{\mathrm{Y}}=25.79+0,51 \mathrm{X}_{2}$ which means that an increase in one expectation score will increase every 0.51 score on satisfaction with teacher colleagues so that results can be accounted for. There is a positive and significant effect of stress control on satisfaction with colleagues. It means that the higher and positive stress control, the higher and positive satisfaction with Teacher Colleagues in MTsN (Islamic Junior High School) Stabat, Langkat Regency by contributing or an effective influence of $28.7 \%$. This means that the variation that occurs in the stress control variable is $28.7 \%$ can be predicted in increasing satisfaction with teacher colleagues. There is a positive and significant influence between expectations and satisfaction with teacher colleagues. This means that the higher and positive expectations, the higher and positive the satisfaction with teacher colleagues by providing an effective contribution of $32 \%$. This can be interpreted that the variation that occurs in the expectation variable of $32 \%$ can be predicted in increasing the satisfaction of teacher colleagues. There is a positive and significant influence together between stress control and expectations together towards the satisfaction of teacher colleagues. This means that the higher and positive stress control and expectations, the higher and positive the satisfaction of teacher colleagues by making an effective contribution of $57 \%$. This means that $57 \%$ of the variation in work satisfaction with teacher colleagues can be predicted by both independent variables. In other words, stress control and expectation together can increase satisfaction with teacher colleagues.

\section{References}

Arikunto, Suharsimi. 1998. Manajemen Penelitian. Cet. 4. Jakarta: Rineka Cipta.

As'ad, 2003. Psikologi Industri.Cet. 8. Yogyakarta: Liberty Yogyakarta.

Azizi, Yahya. 2005. Faktor-faktor yang Mempengaruhi Stres di Kalangan Guru Sekolah Menengah Di Malaysia. Journal Of Educational Enquiry.

Bugin, Burhan, 2011, Metodologi Penelitian Kuantitatif .Edisi kedua.Jakarta: Kencana Prenada Media Group.

Caplan. 1987. "Person-environment fit Theory and Organization." Journal of Vocational Behavior, No. 31.

Colquit Jason A., Jeffry A.LePine, Michael J. Wesson. 2009. Organizational Behaviour: Improving performance and commitment in the workplace. New York: the McGraw-Hill Companies. 
Costa P.T \& McCrae, R.R. 1980. "Influence of Extraversion and Neuroticism on Subjective Well-being", Journal of Personality and Social Psychology, No. 38.

Daft, Richard L. 1988. Management. Chicago: The Dryden Press.

Davis, Keith and John W. Newstrom. 2000. Organizational Behavior : Human Behavior at Work. New York: Mc Graw Hill.

Departemen Agama RI. 2007. Al- Qur'an dan Terjemahannya. Jakarta: Tiga Serangkai Pustaka Mandiri.

Frone. M.R \& McFarlin, D.B 1989. "Cronic Occupational Stressor, Self Focused Attention and Well-being”. Journal of Applied Psychology, No. 74, Vol. 6.

Gibson, J.I., J.M. Ivanevihch. and Donelly, J.H. 2000. Perilaku Organisasi: Struktur, Proses. Jakarta: Bina Rupa Aksara.

Gibson, James L., Jhon M. Ivancevich, and James H. Donnelly, Jr. 1994. Organisasi:Perilaku, Struktur, Proses.Terjemahan Agus Dharma. Jakarta: Erlangga.

Hadari. Martini M dan Hadari Nawawi. 2006. Kepemimpinan Yang Efektif, Yogyakarta: Gadjah Mada University Press.

Hart. P.M, Wearing, A.J \& Heady. B. 1995. "Police Stress and Well-being : Integrating Personality, Coping and Daily Work Experiences." Journal of Occupational \& Organizational Psychology, No. 68, Vol. 2.

Hasibuan, Malayu.2008. Manajemen Sumber Daya Manusia. Cet.11. Jakarta: Bumi Aksara

Ian Percy, 1997. Going Deep, Exploring Spirituality in Life and leadership, (terj. Rudi Ronald), Jakarta: BIP.

Kadarisman. 2012. Manajemen Pengembangan Sumber Daya Manusia. Jakarta: Raja Grafindo Persada.

Karasek. R \& Theorell, T. 1990. Healthy Work, Stress, Productivity and The Reconstruction of Working Life. New York: Basic Books.

Kaswan, 2012. Manajemen Sumber Daya Manusia untuk Keunggulan Bersaing Organisasi.Yogyakarta: Graha Ilmu.

Kenny, Diana T. et al. (2000). Stress and Health : Research and Clinical Applications. Amsterdam: Gordon Breach/Harwood Academic Publisher.

Kreitner. Robert \& Kinicki. Angelo. 2001. Organizational Behavior, Third Edition, Printed in The United State of America: Richard D. Irwin Inc.

Lussier,Robert N. 2009. Management Fundamental. USA: Mason

Mangkunegara, A.A. Anwar P. 2009. Manajemen Sumber Daya Manusia Perusahaan. Bandung: Remaja Rosda Karya.

Martini, Nelly and Dadan Ahmad Fadli. 2010. Pengarus Stres Pekerjaan Terhadap Motivasi Kerja Karyawan Universitas Singaperbangsa Krawang. Jurnal Solusi, Vol. 9 No.17.

Manullang, Marihot. 2008. Manajemen Personalia.Cet. 4. Yogyakarta: Gadjah Mada University Press

Mulyasa, E. 2011. Manajemen dan Kepemimpinan Kepala Sekolah.Cet. 1. Jakarta: Bumi Aksara.

McIntyre. D. 1998. The Politics and Experience of Occupational Stressors, Dissertation, unpublished, Newcastle University.

Moorhead. Griffin. 2003. Organizational Behavior Managing People and Organization. Boston New York: Houghton Miffin Company.

Newstrom, Jhon W. 2007. Organizational Behavior (Twelfth Edition). New York: McGraw Hill. 
Newstrom, John W, \& Keith Davis. 1997. Organizational Behavior: Human Behavior at Work. New York: Mc. Graw-Hill Companies Inc.

Newstrom. John W. 2007. Organizational Behavior : Human Behavior at Work. (USA Mc Graw Hill Companies Inc.

Pace, R. Wayne dan Don F. Faules. 2006. Komunikasi Organisasi (Strategi meningkatkan Kinerja Perusahaan). Bandung: Rosdakarya.

Prabu, A, 2005, Pengaruh Motivasi Terhadap Kepuasan Kerja Pegawai Badan Koordinasi Keluarga Berencana Nasional Kabupaten Muara Enim, Jurnal Manajemen dan Bisnis Sriwijaya vol. 3 No 6

Pedhazur, Elajar J.1973. Multiple Regression in Behavioral Research. Explanation and Prediction. Second edition. Canada: CBS College Publishing.

Quinn, Andrea Jean. (2005). " School Leadership, Culture, and Teacher Stress: Implications for Problem Students". Thesis: Griffith University.

Robbins, Stephen, P. \& Judge Timothy A. 2008. Perilaku Organisasi (Organizational Behavior). Buku 1. Jakarta: Salemba Empat.

Rice. Phillip L. 1999. Stress and Health, $3^{\text {ed }}$. USA: Pacific Grove Brooks/Cole Publishing Company.

Rivai, Veithzal, dan Mulyadi, Deddy. 2011. Kepemimpinan dan Perilaku Organisasi. Jakarta: PT Raja Grafindo Persada.

Rivai, Veithzal dan Deddy Mulyadi. (2011). Kepemimpinan dan Perilaku Organisasi. Jakarta: PT Raja Grafindo Persada.

Rivai, Veithzal. 2009. Islamic Human Capital, (Jakarta: Raja Grafindo Persada.

Rivai, Veitzal. 2008. Manajemen Sumber Daya Manusia Untuk Perusahaan dari Teori ke Praktek. Jakarta : Raja Grafindo Persada.

Siegall. M \& Cumming, L.L. 1995. Stress and Organizational Conflict, Genetic, Social and General Psychology Monographs, Vol. 1 No. 121.

Steers, R.M, \& Porter, L.M. 1983. Motivation and Work behavior. New York: Mac Graw Hill Book Inc.

Subyantoro, A, 2009, Karakteristik Individu, Karekteristik Organisasi dan Kepuasan Kerja Pengurus yang dimediasi oleh Motivasi Kerja (Studi Pada Pengurus KUD Kabupaten Sleman),http;//puslit,petra.ac.id/@journal/index.php/man/article/view File/17740/17661 accessed on 6 Februari 2019

Sudjana, 1989. Metode Statistik. Bandung: Tarsito

Sunarno, A, 2005, Pengaruh Motivasi Kerja, Kepemimpinan Kepala Sekolah dan Lingkungan Kerja guru, pp4

Sopiah, 2008. Perilaku Organisasi. Yoyakarta: ANDI.

Sugiyono, 2009. Metode Penelitian Pendidikan. Pendekatan kuantitatif, kualitattif, dan $R \&$ D. Cet 7. Bandung: Alfabeta

Winardi, J. 2009. Manajemen Perilaku organisasi. Jakarta: Prenada Media Group 